\title{
Film and Literature: A History of Sibling Rivalry ${ }^{1}$
}

\section{(El cine y la literatura. Una historia de rivalidad entre hermanos)}

\author{
Joe Montenegro Bonilla ${ }^{2}$ \\ Universidad Nacional, Sede Regional Brunca, Costa Rica \\ Universidad de Costa Rica, Recinto de Golfito, Costa Rica
}

\begin{abstract}
resumen
El análisis organiza algunas ideas que durante el siglo xx se desarrollaron en torno a la relación entre la literatura y el cine como artes narrativas. Desde una perspectiva histórica, se expone cómo estas disciplinas se han enfrentado y han aprendido a coexistir bajo la cobertura de la semántica como reguladora de los procesos de significación que tanto el cine como la literatura estimulan. Además, se explican las diferencias entre ambas formas artísticas, como «materias de expresión», señalando los puntos de conexión que existen entre ellas para potenciar su análisis comparativo.
\end{abstract}

\begin{abstract}
This analysis addresses ideas which, during the last century, developed around the relationship between literature and film as narrative arts. From a historical perspective, a description is provided about how these disciplines have confronted one another and how they have learned to coexist under the cloak of semantics as a regulator of the signification processes that both cinema and literature stimulate. Moreover, the article discusses the differences between these two art forms, particularly regarding "matters of expression," highlighting the points of connection between the two in order to potentiate their comparative analysis.
\end{abstract}

1 Recibido: 28 de mayo de 2014; aceptado: 27 de junio de 2014.

2 Correo electrónico: montenegrojoe@ hotmail.com

$$
L_{\text {etras }} 55 \text { (2014), ISSN 1409-424X; eISSN 2215-4094 }
$$


Palabras clave: literatura, cine, análisis comparativo, discursos figurativos Keywords: literature, film, comparative analysis, figurative discourse

The study of one specific art form usually implies some questioning of the aesthetic and ideological principles that govern art in general and the various relationships that arise between different artistic practices and genres. After all, as René Wellek puts it, "...the arts are in constant interrelationship, as are all human activities." 3 The particular case of literature and cinema as two related types of creative production, which have come to be intricately related, reveals much of the complexity of comparative studies in the field of the arts. In this respect, Spanish scholar Carmen Peña-Ardid maintains that, in spite of their autonomy and complex signifying models, ${ }^{4}$ literature and cinema are utterly comparable. ${ }^{5}$ Yet the question of how to evaluate both art forms and their connections remains a most intriguing subject of study. Does film translate, influence, parallel or simply react against literature, or is it the other way around ${ }^{6}$ Certainly, there must be a right path to follow that can lead to the deciphering of how and why a movie and a literary text -especially a novel- relate to one another. According to both Peña-Ardid ${ }^{7}$ and the comparatist critic René Wellek, ${ }^{8}$ dialogue is the clue. The dialectical relationships between two types of art are the key to understanding the underlying principles that make it natural for academic audiences to sometimes recognize literature and film as two sides of one subject of study. The comparative approach to the dialogue between the arts has traditionally focused on analogies and differences. ${ }^{9}$ According to Wellek, however, more often than not, " $[\mathrm{t}]$ he analogizing between the arts breaks out into a veritable riot of

3 René Wellek, "The Parallelism between Literature and the Arts," Literary Criticism: Idea and Act (Berkeley: University of California Press, 1974) 44.

4 Carmen Peña-Ardid, Literatura y cine: Una aproximación comparativa (Madrid: Cátedra, 1992) 217.

5 Peña-Ardid, 62.

6 Peña-Ardid, 13.

7 Peña-Ardid, 14.

8 Wellek, 44.

9 Peña-Ardid, 51. 
metaphors," which in the end, amounts to little more than a "harmless game." ${ }^{10}$ In other words, referring to a plastic composition as having a "rhythm" or to a narrative text as showing "photographic qualities" may very well work for comparison but does not provide enough insight into the true relationships between the arts. Therefore, a more accurate approach to the connection between film and literature is the study of the convergences between them, since their association is one of reciprocal borrowing and lending and not one of sheer opposition. ${ }^{11}$ A true comparative analysis will observe how both art forms express themselves and one another.

The relationship between film and literature has not always been one of harmony and balance. Traditionally, it has rather been marked by conflict and struggle for hierarchy and prestige. ${ }^{12}$ According to Robert Stam, "Literature... has often been seen as a more venerable, more distinguished, essentially more 'noble' medium than film." ${ }^{13}$ Consequently, since its beginnings, film came to be regarded as inferior to literature, whereas the latter was actually granted an idealized status, especially by classicist audiences. One of the main reasons for this, Peña-Ardid affirms, is the fact that cinema was, even in its origin, open to the masses, thus becoming subject to the lack of credit and aesthetic prestige that the popular arts of masses have always suffered from. ${ }^{14}$ On the other hand, literature was considered to be "more subtle and precise," 15 and it allegedly demanded a kind of intellectual effort from its readers that film did not require from its spectators. ${ }^{16}$ Some went even further as to declare, says Peña-Ardid, that film was too concrete and superficial, "encontrando verdaderas dificultades para recrear, como la novela, los diferentes procesos

10 Wellek, 48.

11 Peña-Ardid, 48.

12 Peña-Ardid, 15.

13 Robert Stam, Film Theory: An Introduction (Malden, MA: Blackwell, 2000) 12.

14 Peña-Ardid, 26, 46.

15 Stam, 12.

16 Peña-Ardid, 48. 
internos del pensamiento." ${ }^{17}$ As a result, literature was secured a more privileged position than film among the arts.

After more than half a century of rivalry and conflict, however, it became necessary to abandon the old ideas of dependency, hierarchy and inferiority that limited cinematic production. ${ }^{18}$ Film needed to be given the status that it truly deserved as an art form. It had developed up to the point of aesthetic excellence, and by the beginning of the 1950s, its achievements were simply too conspicuous and remarkable not to be regarded as the signs of a true art: the seventh art. Cinema had become, in its own right, a new, independent signifying system, ${ }^{19}$ and as such, it attained equality among the arts, thanks to the comparatist theories that were starting to transform the way in which both film and literature were perceived. Referring to both artistic expressions, Peña-Ardid states, "Creemos que se puede hablar realmente de una auténtica tradición comparativa que reflejaría la enorme riqueza de contrastes y paralelismos que ofrecen ambos dominios." ${ }^{20}$ The relationship between literature and cinema hence became more balanced and started to embrace both reciprocal influence and interdependence as more democratic points of comparison.

Nevertheless, even the comparative tradition to which PeñaArdid refers has not always been successful enough when it comes to finding a scheme of comparison that truly helps delineate the relationship between literature and film. According to Wellek, the arts have traditionally been compared among themselves in terms of emotional effects, intention of the artists, and common social and cultural backgrounds. ${ }^{21}$ However, all of these methods have proven faulty in one way or another. This is where semiotics comes into the picture. By the end of the 1960s, film scholars like Christian Metz, Roland Barthes, P.Paolo Pasolini, Umberto Eco, and others had started

17 Peña-Ardid, 174.

18 Peña-Ardid, 28.

19 Peña-Ardid, 52.

20 Peña-Ardid, 90.

21 Wellek, 57-59. 
to turn to semiology and structural linguistics for an answer to the question of film language and its relationship with literary language -an issue that will be addressed later. ${ }^{22}$ As a result, the question of the film-literature comparative complex was best addressed by semiotics, although not unvaryingly or without controversy.

Two seemingly contradictory analytical branches sprouted out from the semiotic approach: one focused on content and the other on structure. According to Jorge Urrutia, "la comparación cine-literatura sólo es posible a partir de la problemática del plano del contenido." 23 For Urrutia, as for a number of other experts, the comparison between cinematic and literary texts lies in narrative configuration and plot development, and not in linguistic or audiovisual aspects. ${ }^{24}$ Content, he affirms, is common to all semiotic phenomena. ${ }^{25} \mathrm{On}$ his side, Umberto Eco seems to agree with some of these presuppositions, yet he digs a little deeper into the comparative aspects of film and literature. He asserts that both art forms are arts of action, ${ }^{26}$ narrated in literature but represented in film. ${ }^{27}$ However, Eco also explains that film and literature share more than a story-telling function: they are also structurally homologous. ${ }^{28}$ Here is where the second branch of semiotic comparison steps into the light. "Obviously," Wellek claims, "the most central approach to comparison between the arts is based on an analysis of the actual objects of art, and thus of their structural relationships." 29 This community among the arts," Wellek later establishes, "... should be studied in the structural relationships between the arts..." ${ }^{30}$ In any event, semiotics remains the most current

\footnotetext{
22 Peña-Ardid, 43-44.

23 Qtd. in Peña-Ardid, 128.

24 Qtd. in Peña-Ardid, 103, 128.

25 Peña-Ardid, 194.

26 Qtd. in Peña-Ardid, 131, 189.

27 Qtd. in Peña-Ardid 189.

28 Qtd. in Peña-Ardid 189.

29 Wellek, 60.

30 Wellek, 64.
} 
and acknowledged approach to the comparative analysis of the arts, especially film and literature.

The phenomenon of the exchange of semiotic systems, both in terms of content and of structural features, is gaining the attention of film critics and scholars nowadays. ${ }^{31}$ One of these experts,André-Marie Rousseau, explains the current semiotic movement as follows: “... preferimos postular un universo global de signos, apelando a la vez a la sensación y a la significación, manifestado por diversos media que se encabalgan en parte por la forma, el contenido y las miras." 32 Rather "hesitantly," as he himself admits doing, Wellek goes one step further to suggest "that the approximation among the arts which would lead to concrete possibilities of comparison might be sought in an attempt to reduce all the arts to branches of semiology." ${ }^{33} \mathrm{As}$ unsettling and frontward as this may sound, it certainly provides a clear idea of where the comparative criticism of film and literature is headed, and more importantly, it sets the foundations for the analysis of film adaptations of literary texts.

Both the comparative contents and the structural relationships between literature and cinema are crisscrossed by a series of formal components that are closely related to their mediums and to the sensorial data that they supply. In this regard, Stam explains that "...each art form has uniquely particular norms and capabilities of expression." ${ }^{34}$ This premise is known as "medium specificity." ${ }^{35} \mathrm{It}$ is precisely through this specificity, however, that the semantic comparisons available between the two arts are most accurately arrived at since the natural relationship between the arts is one of sharing what is specific to each. For a comparison to be meaningful, therefore, it should take into account particular matters of expression, i.e., "the

\footnotetext{
31 Peña-Ardid, 16, 153, 213.

32 Qtd. in Peña-Ardid, 91.

33 Wellek, 65.

34 Stam, 12.

35 Stam, 11.
} 
material in which signification manifests itself." ${ }^{36}$ After all, the meaning of literary and cinematic texts lies in the articulation of their semantic elements, ${ }^{37}$ and the signifiers are never separated from the matters of expression engaged in the artistic production. ${ }^{38}$ Accordingly, the comparison between film and literature starts with the comparison between their distinctive matters of expression. Stam outlines the difference as follows:

Literary language $\ldots$ is the set of messages whose matter of expression is writing; cinematic language is the set of messages whose matter of expression consists of five tracks or channels: moving photographic image, recorded phonetic sound, recorded noises, recorded musical sound, and writing (credits, intertitles, written materials in the shot)..$^{39}$

Rather than separating film from literature, the multiplicity of the former's matter of expression makes it comparable to the written text since it enlarges the possibilities for contrast and association between the two. ${ }^{40}$ Even so, the number of ways in which film can express meaning is larger than that available for literature.

As opposed to the literary text, cinema has access to a variety of semiotic levels that are made effective by more than one single mode of expression. Firstly, it is true that the basic matter of expression in film is the photographic image. David Bordwell and Kristin Thompson explain that what they call "the cinematographic qualities of the shot" as involving "not only what is filmed [mise-en-scène], but also how it is filmed"; in other words, the photographic image, the framing, and the duration of the shot. ${ }^{41}$ Of the three, they assure,

36 Stam, 112.

37 Peña-Ardid, 214.

38 Peña-Ardid, 129.

39 Stam, 112.

40 Peña-Ardid, 156.

41 David Bordwell and Kristin Thompson. Film Art: An Introduction (New York: Alfred A. Knopf, 1986) 151. 
photography is what gives the most control to the filmmaker, and cinematography depends on photography, which regulates color, speed, and perspective. ${ }^{42}$ The semiotic possibilities that both photography and cinematography offer account for much of the richness of film as a form of artistic expression.

Nevertheless, film also consists largely of sound-even the first silent movies depended on music to spawn the action. The element of hearing is as important as that of seeing, since it expands the cinematic matter of expression and allows for more possibilities of signification. ${ }^{43}$ According to Bordwell and Thompson, "Many people tend to think of sound as simply an accompaniment to the real basis of cinema, the moving images." ${ }^{44}$ However, sound is autonomously treated in the production of a film, and some of its advantages-engaging a second sense mode, shaping interpretation of the image, and directing attention within the image ${ }^{45}$-are equally responsible for the overall effect of the film experience. Film is then driven by expressive tracks that appeal to a minimum of two different senses, which, at least at first, cannot be said of literature.

The meaning of cinema, says Peña-Ardid, lies in its heterogeneity of codes and materials. ${ }^{46}$ Assertions like this have often been admitted as proof of the vindication, if not the superiority, of film over literature. Stam adds:

... it could... be argued that cinema, precisely because of its heterogeneous matter of expression, is capable of greater complexity and subtlety than literature. Cinema's audiovisual nature and its five tracks authorize an infinitely richer combinatoire of syntactic and semantic possibilities. The cinema has extremely varied resources... ${ }^{47}$

42 Bordwell and Thompson, 151.

43 Peña-Ardid, 150.

44 Bordwell and Thompson, 232.

45 Bordwell and Thompson, 232, 234.

46 Peña-Ardid, 157.

47 Stam, 12. 
Ironically enough, cinema seems to have reached a position in which-it might be said-it has received compensation for all the rejection and neglect that it suffered in its beginnings. Film now enjoys the prestige and status that it was once denied since it has become perceptually richer. According to Metz, "The cinema's signifier is perceptual (visual and auditory [as well as tactile, for that matter]). So is that of literature, since the written chain has to be read, but it involves a more restricted perceptual register." ${ }^{98}$ Film, therefore, appears as more perceptually prolific than literature.

Nevertheless, it is also said that the visual qualities of literature involve more than just the optical experience of reading a written text. The notion of verbal picture introduced by Wellek and Warren attempts to explain this conception. ${ }^{49}$ Reading is seeing in the mind, they allege. Thus, a literary text can create vision and visual precision, which accounts for much of its verisimilitude. ${ }^{50} \mathrm{In}$ sum, both literature and cinema are visually productive, and their matters of expression are both multiphased, although that of film is unquestionably more resourceful. Seen as a language and defined by an attractive plurality of codes and matters of expression, cinema results highly heterogeneous. ${ }^{51}$ This heterogeneity cannot be said to be a necessary component of literature as it is of film.

Given that both literature and film follow their own structural rules and act in accordance with their distinct matters of expression, it seems logical to claim that their languages also differ from one another. Although both literature and cinema are figurative discourses,${ }^{52}$ their communicative codes work differently to achieve meaning and signification. Their semantic ends may be the same, or at least analogous, yet their linguistic means are poles apart. Ever since its beginnings,

48 Christian Metz, "The Imaginary Signifier," The Film Studies Reader, Eds. Joanne Hollows et al. (London: Arnold, 2000) 214.

49 Qtd. in Peña-Ardid, 112.

50 Qtd. in Peña-Ardid, 114.

51 Peña-Ardid, 53, 88.

52 Peña-Ardid, 131. 
cinema faced the question of finding a language of its own, different from that of literature. ${ }^{53}$ During the 1960s and 1970s, the criticism of the new art devoted much of its effort to study film language and where it stood with regard to verbal-literary language. ${ }^{54}$ If anything, film critics and scholars of the time arrived at the conclusion that film language was to be treated in its own right, and that the language of literature -the language of words -was not no longer the only option available for artistic narrative. Although, as Boris Eichenbaum puts it, film language is not at all oblivious to verbal language $;{ }^{55}$ the former cannot be studied in terms of the latter ${ }^{56}$ for cinema has earned a position of linguistic autonomy.

From the start, however, the issue of film language brought about its own questions. How did it work? What were its rules and components? How could it be read? As has always been the inclination of comparative criticism among the arts, metaphoric notions like film-word and film-phrase were the first forms available to resort to. ${ }^{57}$ Nonetheless, “...para convertir el cine en arte,” Peña-Ardid explains after Emilio Garroni, "se [quería] encontrar una lengua cinematográfica, un código único y un modelo homogéneo." 58 The search for linguistic autonomy then was the agenda of film criticism during the second half of the century, but the idea of homogeneity soon proved naïve and far-fetched. After all, cinema was a combination of "modelos textuales en los que intervienen... varios códigos -analógicos, iconográficos, narrativos, ideológicos." ${ }^{\circ 9}$ Film was surely to be regarded as having a particular language, and such language could be anything but homogeneous.

\footnotetext{
53 Peña-Ardid, 34, 64.

54 Peña-Ardid, 43.

55 Qtd. in Peña-Ardid, 68.

56 Qtd. in Peña-Ardid, 87.

57 Peña-Ardid, 64.

58 Peña-Ardid, 88.

59 Peña-Ardid, 215.
} 
All the same, Stam recounts that semiotics led the film critics of the 1960s and 1970s to develop filmolinguistics, whose project was "to define the status of film as a language." ${ }^{60}$ Then another reasonable question emerged: "Is cinema a language system (langue) or merely an artistic language (langage)?" ${ }^{61}$ The true difference between film language and natural verbal language was thus finally established. According to Metz, "the cinema does not constitute a language widely available as a code." ${ }^{62}$ No one can learn and then "speak" cinema as they can speak French, German or English. The cinematic language is to be invented, created all along. Stam explains:

There is, furthermore, a fundamental difference in the diachrony of natural as opposed to cinematic language. Cinematic language can be suddenly prodded in a new direction by innovatory aesthetic procedures... Natural language, however, shows a more powerful inertia and is less open to individual initiative and creativity...

Metz concluded that the cinema was not a language system but that it was a language. ${ }^{63}$

In view of this, as already established, film language cannot be described or studied in terms of natural language; and speaking in semiological terms, it has to be approached as a signifying practice that makes use of its own communication codes and matter of expression to convey a particular message.

The way to uncover the nature of film language and its relationship with verbal language was then supplied by semiotics, hence the basis that this science provides for film linguistics. "...the object of semiotic research," says Stam, "[is] anything that [can] be construed as a system of signs organized according to cultural codes and

60 Stam, 107.

61 Stam, 108.

62 qtd. in Stam, 111.

63 Stam, 112. 
signifying processes... ${ }^{964}$ Under such category falls cinema, since it does not just juxtapose iconic signs but opposes semantic units. ${ }^{65}$ The semiotic analysis of cinema, therefore, makes it possible to appreciate and understand its linguistic structure and artistic integrity. It is only through the breakdown and study of these signifying units and the relationship among them that cinema acquires any value as artistic creation. Such semiotic components are what Metz calls "syntagmas," i.e., "units of narrative autonomy in which elements interact semantically." "The shot, the scene, the sequence, the parallel montage, and the autonomous plane are some examples of syntagmas. ${ }^{67}$ Metz also explains, "Language selects and combines phonemes and morphemes to form sentences; film selects and combines images and sounds to form 'syntagmas'..." ${ }^{98}$ In other words, syntagmas are the bricks of cinema, just like the spoken and written words are those of language. However, in spite of all the differences between film language and verbal literary language, the "true analogy" between the two lies in their "common syntagmatic nature." ${ }^{\circ 9}$ In the end, both film and literature are semantically driven.

Semiotics also paves the way for a film grammar to emerge. The syntagmatic components of cinema are then organized in a way resembling the linguistic syntax that rules any verbal production -literature included. As Metz puts it, "Existe una organización del lenguaje cinematográfico, una suerte de 'gramática' del film, que no es arbitraria... ni inmutable..." ${ }^{" 70}$ The minimal unit of such cinematic syntax is the plane ${ }^{71}$ and the formal and discursive analysis of its narrative components focuses on bigger units like sequences and

64 Stam, 107.

65 Peña-Ardid, 107.

66 Qtd. in Stam, 115.

67 Christian Metz, "La gran sintagmática del film narrativo," Análisis estructural del relato, 4th ed, Eds. Roland Barthes et al. (Buenos Aires: Eitorial Tiempo Contemporáneo, 1974) 148-150.

68 Qtd. in Stam, 115.

69 Qtd. in Stam, 115.

70 Metz, 152.

71 Peña-Ardid, 87, 157. 
groups of sequences. ${ }^{72}$ In other words, the various syntagmas that Metz describes act conjointly and integrally to generate structural unity and fluency in what is understood as the syntax of film. This is how the cinematic language works to create a narrative that is invented and organized along the process. Furthermore, Sergei Eisenstein also equates the cinematic syntax to the idea of montage ${ }^{73}$ since it resorts to juxtaposition, coordination, subordination and other syntactical processes in the same fashion as verbal grammar does. ${ }^{74}$ In sum, cinema is governed by the rules of a linguistic code that, although more flexible and releasing than that of verbal-literary language, still exerts an organizing force over its nature.

The linguistic systems of film, however, never stop at the grammatical level, for they are always evident in the shape of diverse matters of expression. They are translated into audiovisual experiences, and from there, through montage and through the relationship between sound and image, they reach the realm of narrative. ${ }^{75}$ It is the combination of auditory and visual elements what gives life to the linguistic achievement of film, yet it is the image itself what presides the overall experience. According to Peña-Ardid, cinema consists of the reading of images and the relationships among them. ${ }^{76}$ Once again, the linguistic nature of film is manifest.

Nevertheless, as Pere Gimferrer puts it, cinema is ultimately "el arte de la imagen," "77 and Roland Barthes also gave the cinematic image a superior role within the complex of semiotics. He attached symbolic value to it and defined it as a signifier without signified, ${ }^{78}$ thus underlining its unparalleled figurative and narrative power. ${ }^{79}$ The immediacy of meaning that Barthes believes to determine the semiotic

\footnotetext{
72 Peña-Ardid, 87.

73 Qtd. in Peña-Ardid, 74.

74 Qtd. in Peña-Ardid 197.

75 Peña-Ardid, 144.

76 Peña-Ardid, 70.

77 Qtd. in Peña-Ardid, 34.

78 Qtd. in Peña-Ardid, 161.

79 Peña-Ardid, 130.
} 
value of image makes it-as opposed to the written word of the novel, for example-an extremely prolific matter of expression, since it generates meaning at multiple levels, even at the level of the symbolic. "Las ideas abstractas," says Peña-Ardid, "parecen formularse en el film a partir de representaciones concretas e individuales, otorgando a la imagen un valor simbólico..." ${ }^{80}$ Yet the symbolism of the cinematic image is but part of the semiotic potential that it may realize. Throughformal procedures like composition, framing, and perspective, Peña-Ardid argues, "la imagen de lo real se ha convertido en 'signo semántico,' esto es, en un elemento del lenguaje cinematográfico." ${ }^{11}$ The cinematic image is pure, concentrated signification, for it is the actual materialization of film language and the semiotic essence of cinema as a whole.

The iconic image has proven crucial for the development and acceptance of film as a language, yet it has not reached such a status without struggle. As it was established above, the relationship between film and literature has been marked by conflict and opposition, but such rivalry stems from a more primitive struggle, that of the image versus the word. On the one hand, literature is mediated by verbalization; on the other, cinema is based on iconic representation. ${ }^{82}$ Thereby, the points of connection between the two arts are once again overshadowed by their differences and disagreements. The explanation resides in the fact that both image and word have fallen prey to the ancient antagonism between the visual and the verbal, a necessary consequence of the logocentric culture that interweaves them. ${ }^{83}$ In general terms, the iconic image has always been considered inferior to the word. Verbal language, Eco maintains, is conventional, abstract, and arbitrary, whereas the iconic image is analogical, concrete, and mimetic-representative. ${ }^{84}$ The word is more accessible than the image, since it is more readily at handand

80 Peña-Ardid, 163.

81 Peña-Ardid, 65.

82 Peña-Ardid, 155.

83 Peña-Ardid, 47.

84 Qtd. in Peña-Ardid, 156. 
more structurally and formally defined. Consequently, it is said that the iconic image "no ha alcanzado un grado de formalización siquiera aproximado al del lenguaje verbal." ${ }^{85}$ Such antagonism and disparity underpin only the already existing ones between literature and film since, although the latter is not completely alienated from the word, ${ }^{86}$ its quintessential dependence on the iconic image makes it vulnerable to its alleged weaknesses.

Verbal and iconic languages, without a doubt, are in essence dissimilar. Their management of abstraction and concreteness and the processes of rationalization that they spur are in fact divergent. However, as Peña-Ardid puts it, “...las imágenes cinéticas y la cadena de signos discretos de la lengua comparten algunos rasgos 'sensibles' comunes: la temporalidad y la secuencialidad." ${ }^{87}$ Hence both literature and film are perfectly able to portray narrative. In any event, the iconic image and the word are not purely opposite. Their similarities may not be many, but their artistic potentials are equivalent, and their ways of accessing meaning are likewise effective. According to Eco, in word-arts like literature, readers are provoked by a linguistic sign and then led into conceptualization by the evocation of an image, which in turn stimulates them emotionally, whereas in image-arts like film, the stimulus comes directly from the image, thus postponing the possibility of conceptualization and rationalization to give way to a more immediate emotional response. ${ }^{88}$ Rather than opposing one type of art to the other, Eco highlights the varying ways in which art can incite meaning. Similarly, Gianfranco Bettetini emphasizes the complementariness between literature and cinema when he refers to the relationship between the abstract and the concrete as addressed differently by iconic representation and verbal language. He maintains: "Mientras la primera [cinema] accede a la abstracción por medio del

85 Peña-Ardid, 158.

86 Peña-Ardid, 48.

87 Peña-Ardid, 129.

88 Qtd. in Peña-Ardid, 160-161. 
encadenamiento de imágenes, el segundo [literature] precisa de la yuxtaposición de palabras para construir lo concreto y lo individual." ${ }^{99}$ In conclusion, the most accurate approach to the relationship between the iconic image and the word does not observe them as rivals or semiotic opponents, but as two separate means of expression, as two components of the same signifying artistic whole.

In the midst of the many unremitting attempts to equate image to word in the context of film language, an obstacle has been found. Much has been said about the equivalence of the former with regard to the latter, yet there might be another linguistic form to which the cinematic image can more accurately relate. Metz, for whom the syntagmatic articulation of film is the true recipient of signification, states that the image is a unit of discourse (language in use) as opposed to a unit of language (linguistic system),${ }^{90}$ which forces him to look for other, more encompassing possibilities of syntactic comparison between cinema and literature. As a result, Metz proposes the cinematic image-the shot-to be made equivalent not to the word but to the phrase or the statement. ${ }^{91}$ In this sense, some of the tension between the iconic and the verbal is released.

Stam explains Metz's view in terms of the disanalogies between shot and word. So, among some of the misled connections between the word and the cinematic image, he reports that the former is limited, preexistent, virtual, and paradigmatic, whereas the latter is infinite, original, actualized, and open to meaning. ${ }^{92}$ As a matter of fact, “... Metz's more general point," says Stam, "is that the cinematic shot more closely resembles an utterance or a statement... than a word." ${ }^{93}$ In the same fashion, Stam continues, "Bettetini argued that the minimal signifying unit of film, the 'cineme' or 'iconeme' [analogous to the morpheme or phoneme], is the filmic image, and this corresponds

89 Qtd. in Peña-Ardid, 163-164.

90 Qtd. in Peña-Ardid, 87.

91 Qtd. in Peña-Ardid, 87, 157.

92 Stam, 110-111.

93 Stam, 111. 
not to the word but to the sentence." ${ }^{94}$ Whether as a linguistic or as a discursive unit, the iconic image remains the semiotic basis of film. Thus deciphering of its position within the structure of the cinematic language has often been a priority for film semiologists and critics. The cinematic image may be equated to word or to sentence, yet whatever the case, the focal point is that, in spite of all their differences, the filmic and the natural verbal language used in literature are not opposites but semiotic equivalents. As Román Gubern puts it, even among all the differences that separate verbalization from the iconic representations of film language, there are no deterministic possibilities but only "procesos diferentes de acceder al sentido." 95 In spite of their historical rivalry, literature and cinema remain sister arts in a family of signification.

Regardless of their differences, literature and cinema have managed to survive throughout decades as two of the most cherished forms of artistic creation. Their combination of narrative affinity and sensorial engagement has placed them above other less diverse, less popularly appealing arts. Their relationship has conquered myriad obstacles, ranging from the very nature of their cultural and artistic origin and status to the differing semiotic systems that both limit and drive their productions. Their history is one of sibling rivalry, yet also one of sisterhood. On the one hand, they speak different languages and behave in different, sometimes opposing ways; on the other, they borrow and lend from one another and, more and more increasingly, are starting to be thought of always in relation to one another. Like rival twins, their existences are necessarily bound together. They may envy each another, but in spite of themselves, they may also end up adopting the other's demeanor. Fortunately enough, the antagonism between these two arts seems, especially more recently, to be receding. It is now giving way to a more sisterly society in which semiotics has taken over.

94 Stam, 114.

95 Qtd. in Peña-Ardid, 164. 